\title{
Enhanced excretion of thioethers in urine of operators of chemical waste incinerators
}

\author{
R VAN DOORN, CH-M LEIJDEKKERS, R P BOS, R M E BROUNS, AND \\ P TH HENDERSON
}

From the Institute of Pharmacology and Toxicology, University of Nijmegen, Nijmegen, The Netherlands

ABSTRACT Thioether concentrations were determined in urine samples obtained from ten workers in the despatch department $(n=69)$, three chemical waste incinerator operators $(n=67)$, and an analyst $(n=21)$, all working in the same chemical plant. Urine samples $(n=196)$ obtained from non-exposed men, including smokers, served as controls. Enhanced excretion of thioethers was found in urine samples taken from incinerator workers at the end of work. A regular pattern in the time course of the urinary thioether excretion was shown by a non-smoking incinerator worker; end-ofwork values were always higher than prework values. This phenomenon was not found in samples obtained from the analyst. These findings suggest that incinerator workers inhale or otherwise absorb electrophilic compounds or their precursors, which are subsequently metabolised to, and excreted as, thioethers in urine.

In assessing the risks to health from chemical substances exposure data as well as toxicity data are required. Recently much progress has been made in detecting toxic properties of chemicals by introducing short-term screening methods for mutagenic and carcinogenic compounds. ${ }^{1-5}$

In the near future the aim must be to investigate and evaluate the toxic properties of all compounds before their large-scale production and use. Toxic compounds must be eliminated from the environment wherever and whenever possible.

Reduction of industrial exposure levels contributes to the safety and health of workers exposed to toxic chemicals. Reliable parameters of exposure are thus of great importance. When the air in the working environment is contaminated with certain known chemicals the most obvious approach is to measure concentrations in the air.

More directly related to health risks, however, is biological monitoring - that is, the measurement of internal exposure through analysis of a biological specimen that contains polluting compounds or their metabolites. ${ }^{6}$ Examples are the determination of hippuric acid in urine after exposure to toluene ${ }^{78}$ and the determination of urinary mandelic and phenylglyoxylic acids in exposure to styrene. ${ }^{910}$ Whenever possible, selective methods must be

Received 1 March 1980

Accepted 23 May 1980 preferred in biological monitoring. Thus far, however, only a limited number of exposure tests have been described and evaluated. In addition, in many instances workers are exposed to a mixture of chemicals. Therefore, non-selective assays also have their value-for instance, as a first step in developing selective tests.

Non-selective assays for determining exposure to toxic chemicals include the determination of mutagens in urine ${ }^{11} 12$ and the determination of mercapturic acids in urine..$^{13}$ Mercapturic acids and other thioether compounds are the end products in the detoxication of electrophilic agents through conjugation with glutathione..$^{1516}$ Recently it was shown that thioethers as well as mutagens are excreted in the urine of cigarette smokers. ${ }^{17}$

In the present study we describe the application of a thioether assay to urine samples from operators of chemical waste incinerators. These workers are exposed to a mixture of chemicals including benzene, ethylbenzene, styrene, and many polymeric compounds and their combustion products.

\section{Materials and methods}

\section{SUBJECTS}

Thirty-four prework and 33 end-of-work urine samples were collected from three operators occupied with chemical waste incineration. A further 69 urine samples from 10 people working in the despatch 
department and 21 samples from a chemical analyst working in the same chemical plant were obtained.

The samples were stored for up to three weeks at $4^{\circ} \mathrm{C}$ until brought to our laboratory. On arrival they were frozen at $-20^{\circ} \mathrm{C}$ until required. If there are facilities to store urine at $-20^{\circ} \mathrm{C}$ we recommend that urine samples be frozen after collection. Otherwise the samples should be assayed as soon as possible, because a decrease in the urinary thioether concentration of up to $15 \%$ (depending on the thioethers present in the samples) may occur during storage for two weeks at $4^{\circ} \mathrm{C}$.

To establish normal values for urinary thioether concentrations 196 urine samples were obtained from non-exposed men, including cigarette smokers. These urine samples were collected at random during the day.

\section{CREATININE ASSAY}

The creatinine content of the urine samples was measured with an automated analyser method based on the reaction of creatinine with alkaline picrate, as described by Gorter and De Graaff. ${ }^{18}$ Urinary thioether concentrations were determined in samples with a creatinine content of $5.0 \mathrm{mmol} / \mathrm{l}$ or higher.

\section{THIOETHER ASSAY}

Thawed urinc samples were centrifuged for five minutes at $3000 \mathrm{~g}$ before processing. Aliquot samples of $5.0 \mathrm{ml}$ of clear urine were transferred into glassstoppered tubes, and the $\mathrm{pH}$ was adjusted to $1 \cdot 5-2 \cdot 0$ with $4 \mathrm{~N} \mathrm{HCl}$. After the addition of $8.0 \mathrm{ml}$ of ethyl acetate the layers were shaken vigorously for 15 minutes using a shaking apparatus. The layers were separated by centrifugation at $3000 \mathrm{~g}$ for five minutes. After removal of the ethyl acetate layer the extraction procedure was repeated with another $8.0 \mathrm{ml}$ of ethyl acetate.

The collected ethyl acetate layers were evaporated to dryness using a rotary evaporator. The residue was taken up in $2.0 \mathrm{ml}$ of aqua dest. Alkaline hydrolysis was performed on $1.0 \mathrm{ml}$ samples in brown-glass screw-capped tubes by the addition of $0.5 \mathrm{ml}$ of $4 \mathrm{~N} \mathrm{NaOH}$, saturation with nitrogen, and keeping the closed tubes in a boiling waterbath for 50 minutes. Then the tubes were cooled in ice for 10 minutes. Under mixing $0.5 \mathrm{ml}$ of $4 \mathrm{~N} \mathrm{HCl}$ was added. Exactly five minutes later the SH-concentration was determined according to Ellman ${ }^{19}$ with slight modifications. A $0.25 \mathrm{ml}$ aliquot sample of the aqueous solution was added to a freshly made mixture consisting of $2.0 \mathrm{ml}$ of $0.5 \mathrm{M}$ phosphate buffer $(\mathrm{pH}=7 \cdot 1)$ and $0.3 \mathrm{ml}$ of a $5,5^{\prime}$-dithiobis(2-nitrobenzoic acid)-solution ( $0.4 \mathrm{mg}$ DTNB per $\mathrm{ml}$ of $1 \%$ sodium citrate solution). Absorbances were read at $412 \mathrm{~nm}$ on a Pye Unicam SP 1750 spectro- photometer. Corrections were made for the contribution of the extract and of the DTNB-solution to the absorbance. The SH-concentration was calculated from the corrected absorbance and the molar absorbance of the reference compound $\mathrm{N}$-acetyl-Lcysteine in the SH-determination.

Thioether concentrations of urine samples were expressed in mmoles $\mathrm{SH} / \mathrm{mole}$ creatinine. No corrections were made for the presence of thiols, disulphides, or thioesters in the extracts.

\section{Results and discussion}

Application of the thioether assay to urine samples of the non-exposed people showed the presence of a background, as is shown in figure 1. These samples were collected at random during the day and included samples obtained from smokers.

The limits of the normal values were determined by application of the procedure described by Rümke and Bezemer. ${ }^{20}$ The mean value of the urinary thioether concentration was $3.8 \mathrm{mmoles} \mathrm{SH} / \mathrm{mole}$ creatinine and the outer limit of the percentile $\mathbf{P}_{95}$ $(\gamma=90 \%)$ was calculated to be $5.9 \mathrm{mmoles} \mathrm{SH} / \mathrm{mole}$ creatinine. The latter should be regarded as a warning limit; by this method of statistical analysis it can be constituted with $90 \%$ confidence that at most $5 \%$ of a non-exposed population have urinary thioether values above $5.9 \mathrm{mmoles} \mathrm{SH} / \mathrm{mole}$ creatinine.

Figure 2(a) shows the prework and end-of-work distribution pattern of thioether values in urine samples of chemical waste incinerator operators. The mean value in prework urine samples was

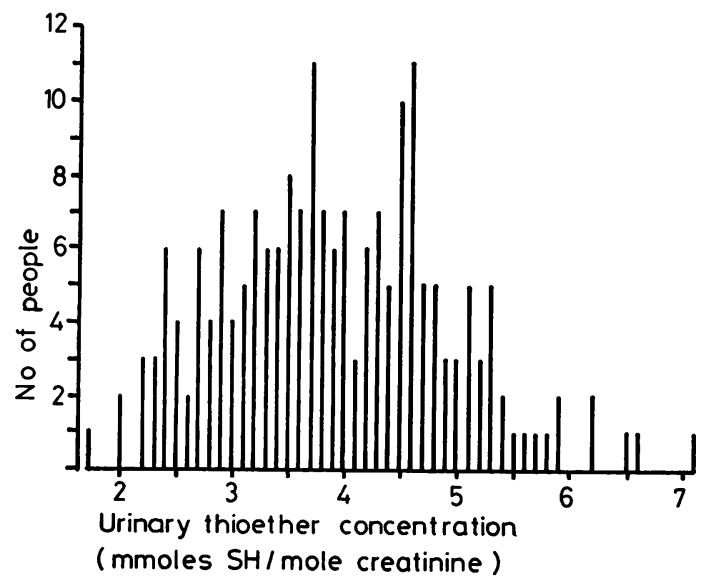

Fig 1 Distribution of thioether concentrations in a group of 196 urine samples obtained from non-exposed men (including cigarette smokers). 

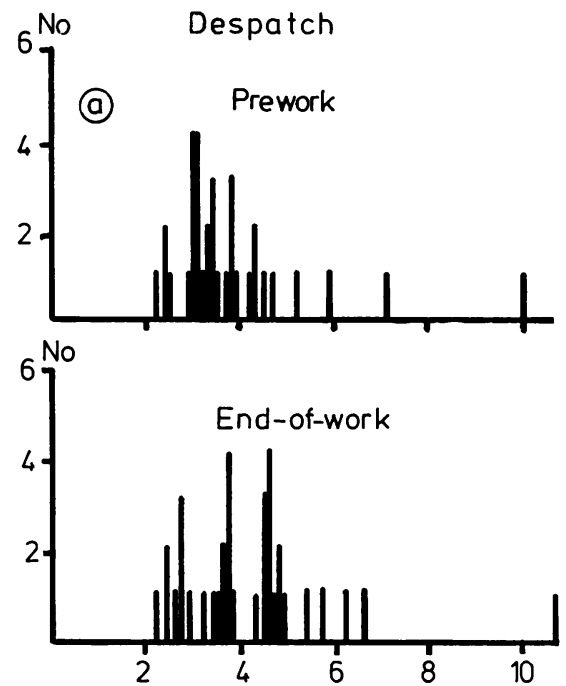

Thioether (mmoles $\mathrm{SH} /$ mole creatinine)
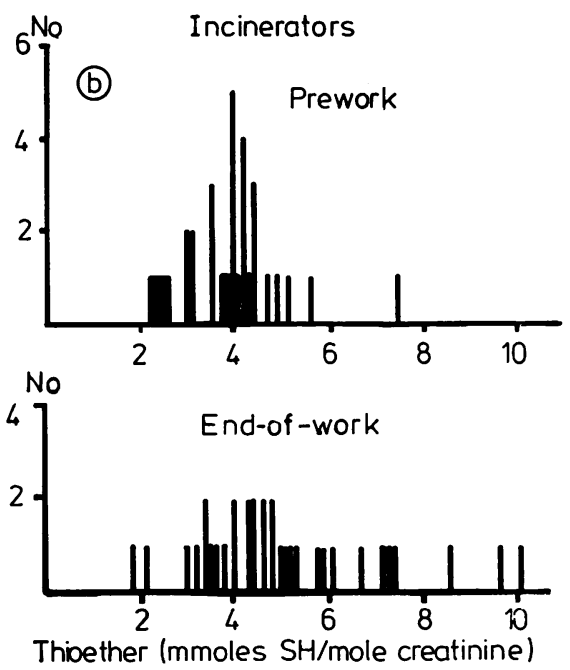

Fig 2 Thioether concentrations in prework and end-of-work urine samples obtained from $(a)$ three operators of chemical waste incinerators $(n=67)$ and (b) ten people working in the despatch department $(n=69)$.

$3.9 \mathrm{mmoles} \mathrm{SH} /$ mole creatinine with $3 \%$ of the values exceeding the percentile $\mathbf{P}_{95}$ mentioned above. The mean value in the end-of-work samples was $5.1 \mathrm{mmoles} \mathrm{SH} / \mathrm{mole}$ creatinine, and $24 \%$ crossed the warning limit.

Such a difference was not found in samples from workers of the despatch department (fig 2(b)). The mean values of pre- and end-of-work urines were
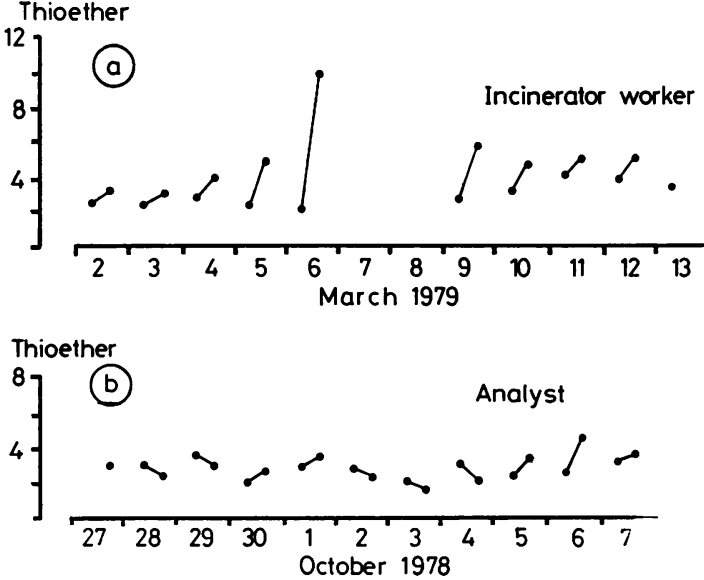

Fig 3 Time course in urinary excretion of thioethers by workers of a chemical plant. (a) Samples from a non-smoking incinerator worker. (b) Samples from a non-smoking analyst. Urinary thioether concentrations are in mmoles $\mathrm{SH} /$ mole creatinine.

3.8 and $4.0 \mathrm{mmoles} \mathrm{SH} /$ mole creatinine respectively with $6 \%$ and $9 \%$ of the values exceeding the $\mathrm{P}_{95}$ limit. Enhanced thioether excretion in the end-ofwork urine of incinerator workers is unlikely to be caused by cigarette smoking; only one of the three incinerator workers is a smoker whereas four out of ten despatch workers are smokers.

Figure 3(a) shows the time course of the thioether excretion in urine of one of the non-smoking incinerator workers during a 12-day period. Each day the postwork thioether value was higher than the values at the beginning of a work period. Such regular patterns were not found in urine samples obtained from a chemical analyst (fig 3(b)). We conclude, therefore, that the enhanced thioether excretion is due to a diurnal rhythm. These findings indicate that there is a positive relation between the exposure of the operators during incineration work and the excretion of thioethers in urine. On the other hand, the exposure of the analyst and the workers of the despatch department to toxic chemicals cannot be excluded. From these results no conclusions can be drawn as to which compound(s) caused the enhanced excretion of thioethers in the urine of the chemical waste incinerator operators. Most probably, however, electrophilic compounds or their precursors are inhaled or absorbed through the skin and subsequently metabolised to and excreted as thioethers. Identification of the excreted thioethers would open the possibility to develop a selective assay, allowing a more quantitative estimation of internal exposure. 


\section{References}

${ }^{1}$ Stolz DR, Poirier LA, Irving CC, Stich HF, Weisburger $\mathrm{JH}$, Grice HC. Evaluation of short-term tests for carcinogenicity. Toxicol Appl Pharmacol 1974;29:157-80.

${ }^{2}$ Ames BN, McCann J, Yamasaki E. Methods for detecting carcinogens and mutagens with the Salmonella/mammalian-microsome mutagenicity test. Mutat Res 1975; $31: 347-64$

${ }^{3}$ De Serres FJ. The utility of short-term tests for mutagenicity in the toxicological evaluation of environmental agents. Mutat Res 1979;33:11-5.

${ }^{4}$ Brouns RE, Poot M, de Vrind R, van Hoek-Kon Th, Henderson PTh, Kuyper ChMA. Measurement of DNA-excision repair in suspensions of freshly isolated rat hepatocytes after exposure to some carcinogenic compounds. Its possible use in carcinogenicity screening. Mutat Res 1979;64:425-32.

${ }^{5}$ Hollstein M, McCann J, Angelosanto FA, Nichols WW. Short-term tests for carcinogens and mutagens. Mutat Res 1979;65:133-226.

${ }^{6}$ Zielhuis RL. Biological monitoring. Scand $J$ Work Environ Health 1978;4:1-18.

${ }^{7}$ Ogata M, Tomokuni K, Takatsuka Y. Urinary excretion of hippuric acid and $\mathrm{m}$ - or $\mathrm{p}$-methylhippuric acid in the urine of persons exposed to vapours of toluene and $\mathrm{m}$ or p-xylene as a test of exposure. Br J Ind Med 1970;27: 43-50.

${ }^{8}$ Wilczok T, Bieniek G. Urinary hippuric acid concentration after occupational exposure to toluene. $\mathrm{Br} \mathrm{J}$ Ind $\mathrm{Med}$ $1978 ; 35: 330-4$.

${ }^{9}$ Ohtsuji H, Ikeda $\mathrm{M}$. A rapid colorimetric method for the determination of phenylglyoxylic and mandelic acids, and its application to the analysis of urine of workers exposed to styrene vapour. Br J Ind Med 1970;27:150-4.

${ }^{10}$ Ikeda M, Imamura T, Hayashi M, Tabuchi T, Hara I.
Evaluation of hippuric, phenylglyoxylic and mandelic acids in urine as indices of styrene exposure. Internationales Archiv fur Arbeitsmedizin 1974;32:93-101.

${ }^{11}$ Yamasaki E, Ames BN. Concentration of mutagens from urine by adsorption with non-polar resin XAD-2. Cigarette smokers have mutagenic urine. Proc Natl Acad Sci USA 1977;74:3555-9.

${ }^{12}$ Legator MS, Connor T, Stoeckel M. The detection of mutagenic substances in the urine and blood of man. Ann NY Acad Sci 1975;269:16-24.

${ }^{13}$ Seutter-Berlage F, van Dorp HL, Kosse HGJ, Henderson PTh. Urinary mercapturic acid excretion as a biological parameter of exposure to alkylating agents. Int Arch Occup Environ Health 1977;39:45-51.

${ }^{14}$ Vainio H, Savolainen H, Kilpikari I. Urinary thioether of employees of a chemical plant. Br J Ind Med 1978;35: 232-4.

${ }^{15}$ van Doorn R, Henderson PTh. Thioethers in urine als biologische parameter van expositie. Tijoschrift voor sociale Geneeskunde 1979; 57:657-63. (In Dutch.)

${ }^{16}$ Chasseaud LF. The role of glutathione and glutathione S-transferases in the metabolism of chemical carcinogens and other electrophilic agents. Adv Cancer Res 1979;29: 175-275.

17 van Doorn R, Bos RP, Leijdekkers Ch-M, WagenaarsZegers MAP, Theuws JLG, Henderson PTh. Thioether concentration and mutagenicity in urine from cigarette smokers. Int Arch Occup Environ Health 1979;43:159-66.

${ }^{18}$ Gorter E, de Graaff WC. Klinische diagnostick. Leiden: Stenfert Kroese, 1955. (In Dutch.)

${ }^{19}$ Ellman GL. Tissue sulfhydryl groups. Arch Biochem Biophys 1959;82:70-7.

${ }^{20}$ Rümke ChL, Bezemer PD. Methoden voor de bepaling van normale waarden II; nieuwe methoden. Ned Tijdschr Geneeskd 1972;116:1559-68. (In Dutch.) 